\title{
Linking vision with reality in the implementation of policy framework for pastoralism in Nigeria
}

Aminu Ibrahim

Correspondence: aminugas@yahoo. com

Department of Town and Country planning, Ministry of Lands and surveys, Nagogo Road, Katsina, Katsina State P.M.B 2065, Nigeria

\begin{abstract}
The African Union has approved a pastoral policy initiative aimed at securing, protecting and improving the lives, livelihoods and rights of pastoral communities, adopted by the Conference of African Ministers of Agriculture. The African Union urges all African member states to review their policies impacting pastoralism, to develop a comprehensive policy which takes into account the peculiar needs of pastoralism; and to build human, financial and technical capacities to support pastoral policy development. This paper examines some of the challenges which implementation of the policy in Nigeria will face. Typical of most developing countries, most of the factors that are favourable for successful policy implementations are lacking. Therefore, the prevailing complications and distortions with policy making and implementation must be considered. The paper suggests measures to implement the policy.
\end{abstract}

Keywords: Policy framework for pastoralism in Africa, National Action Plan, African Union

\section{Background}

In recent years, global networks and development agencies have shown a growing concern for the improvement of pastoralists' livelihoods. Most recently in January 2011, the Executive Council of the African Union approved a pastoral policy initiative aimed at securing, protecting and improving the lives, livelihoods and rights of pastoral communities. Drawing on extensive regional expert consultations conducted since 2007, the Policy Framework for Pastoralism in Africa is the first continent-wide policy initiative for mobilizing and coordinating political commitment to pastoral development in Africa. The Framework emphasizes the need to fully involve pastoralist women and men in the national and regional development processes from which they are supposed to benefit. The framework also emphasizes the regional nature of many pastoralist ecosystems in Africa and, therefore, the need to support and harmonize policies across the Regional Economic Communities and Member States (African Union 2010). This short article examines how the policy could be successfully implemented in Nigeria.

\section{The policy}

This is the first time that Africa has a continent-wide platform to address the many challenges confronting pastoral communities. It is a welcome development because

(c) 2012 lbrahim; licensee Springer. This is an Open Access article distributed under the terms of the Creative Commons Attribution License (http://creativecommons.org/licenses/by/2.0), which permits unrestricted use, distribution, and reproduction in any medium, provided the original work is properly cited. 
pastoralists often use ecosystems which transcend national borders. While the framework supports the facilitation of fluid boundaries (free movement across political borders), it also provides for regional and national level planning processes for the political, economic and technical resources needed by pastoral communities to better access and sustainably manage their own resources.

The policy framework is formulated to be flexible as a response to the changing trends of pastoralism due to environmental challenges that are becoming increasingly variable. Space has been provided for emerging trends, opportunities and lessons learnt during implementation. While the framework is approved at the continental level, member states are urged to review their policies impacting pastoralism (African Union 2010). Pastoral networks and groups are encouraged to start regional and continental policies, which would facilitate engagement with the Commission, the Regional Economic Communities, other relevant African Union organizations as well as other partners.

The main concern here is how to find a realistic domestication of the provisions of the policy framework in Nigeria, to achieve the desired objectives taking into account the prevailing complications and distortions surrounding policy making and implementation. We should be concerned not just about the formulation of a sound policy, but also how well it can be put it into practice. In most developing countries, programmes and developments are hardly executed in accordance with policy provisions. Some of the challenges the implementation of the policy will face in Nigeria are briefly discussed here.

\section{Poor record of policy implementation}

Nigeria is good in the formulation of policies, but poor at implementation (Onibokun 1998). Comprehensive policies covering virtually all aspects of socio-economic life have always been made often at a very high cost. Such policies appear to be efficient, optimal and appropriate only on paper.

Nigeria is reputed to be good on policy formulation; good on discussing ideas; good on making recommendations; good on spending resources on printing policy documents; but very poor at implementing good ideas and policies. No wonder we remain underdeveloped in the midst of abundant human, material and natural resources!!! (Onibokun 1998, page 2).

The record of Nigerian policy implementation is recognized as very poor. Policies designed to provide solutions to Nigeria's numerous problems have had little or no success (Ekaete 2001). The present state of the economy is nothing other than that of depleted foreign reserve and unprecedented levels of collapse and degeneration of the basic economic structures. Stealing, robbery, thuggery, kidnapping and cultism are the security challenges Nigerians have to contend with while religious and ethnic violence is threatening the corporate existence of the country (Oshewolo 2010). According to Garba (2006), the failure is due to the lack of clearly defined policies with proper guidelines for poverty alleviation, and the policies suffered from political instability, interference and macroeconomic dislocations, as well as lack of continuity, and are riddled with political deception, outright kleptomania and distasteful looting. 
To the pastoralists, the problem goes beyond that of implementation. They are made to contend with defective policies usually based on faulty premises. The history of livestock development in Nigeria reveals a long-standing effort to improve productivity and raise output (Williams 1989) without consideration of pastoral livelihoods. Since independence, two goals of livestock policy have been to raise the low supply of animal protein and to improve and stabilise rural incomes from livestock production and processing (Federal Ministry of Agriculture 1988). The Federal Government will ensure that land for the use and settlement of livestock owners is provided by each state government, to be legally acquired and constituted into grazing reserves for lease allocation to grazers. A sedentarization policy is seen as a strategy to improve pastoralists' living condition, based on the argument that movement is difficult and hazardous, conflicts occur between farming and grazing communities; difficulty in reaching out to the pastoralists for provision of essential amenities, while uncontrolled movement of the Fulani across national boundaries threatens national security. The government lacks clear policies on pastoral Fulani. Not only have they failed, but these policies have also impoverished the Fulani and have made the Fulani lose faith in government programmes (Iro 1995).

\section{Weak pastoralists' voice and organizations}

The absence of a representative and effective pastoral civil society movement capable of articulating the development concerns of its members is one of the key factors that explain the continued marginalization of pastoral communities (Hesse and Odhiambo 2006). Contrary to what is happening in some African states where pastoralists are beginning to have a voice in defending and asserting their rights through well-organized pastoralist organizations often supported by international civil society, in Nigeria, such organizations are lacking. In fact, the Miyetti Allah Cattle Breeders Association of Nigeria, supposedly the single largest association for nomadic and transhumant pastoralists, is run for over a decade without a substantive leadership due to recurring crises in the organization. The activities of the organization are influenced and dictated more by the government(s) rather than the pastoralists. Most pastoralist associations in Nigeria are becoming partisan, usually in support of whichever government is in power. While the pastoralists are taxed continuously, there seems to be little or no efforts by the associations in defending their interest especially in times of conflicts. Most pastoralists are beginning to question the relevance of and losing confidence in these institutions as umbrellas for the protection of their rights.

\section{Growing ethnic violence and intolerance}

Mobility, dictated by the presence of grass and water, is very essential in pastoralism; thus, opportunistic movement of the pastoralists in search of these vital resources has always been its main feature. In the past, the major constraint to transhumant pastoralists was environmental such as the incidence of tsetse fly. Thus, as the pastoralists moved to the grass-rich humid south, the only fear was that of trypanosome and other related diseases. These days, the situation is further compounded by growing ethnic intolerance and violence, often with the pastoralists at the receiving end, and therefore, 
herd mobility is constrained. In the arid northern part of the country, there are sporadic farmer-herder clashes, while in the humid middle belt and south, the situation is catastrophic leading to forced evictions from gazetted rangelands, ethnic cleansing and genocide against the pastoralists. Recently, atrocities against the pastoralists have taken another dimension as there are reported cases of several illegal evictions of the pastoralists from rangelands and some territories by one of the state governments purely on ethnic grounds (Agbese and Lalo 2009; V.O.A 2009).

No amount of policy statements can apply in situations where the laws of the land have not been able to safeguard the human rights of the pastoralists.

\section{Marginalization of the pastoralists}

In Nigeria, pastoral production takes up threequarters of the territory involving all of the northern States and a good part of the central States corresponding to the Sahelian and Sudano-Sahelian agro-ecological zones. Out of a population of 140 million people, the pastoral communities represent about 12 million or about $8.5 \%$ of the populations (1991 estimate, cited in Moutari 2008). Yet, they continue to be left out in decisionmaking, affecting their livelihoods and benefitting little or nothing from developmental programmes/projects. Of the eight environmental/rural development projects implemented in Katsina State, northern Nigeria from 1996 to 2006, none were for the pastoralists (Ibrahim 2006). Over the years, access to their land and other critical resources is undermined. The 1965 Grazing Reserve Law aimed to settle herders in northern Nigeria, through the acquisition of 'native land' for grazing. However, less than $1 \%$ of targeted grazing reserves had been gazetted in the northern states by 1980. In 1988, an ambitious programme to support pastoral livelihoods was launched, aimed to grant $10 \%$ of national territory as grazing reserves for lease allocation to herders, an effort by the central government to protect pastoralism, but that has not been enforced; by 1998, of the 313 grazing reserves acquired, only 52 were gazetted, and even these reserves have been intruded into by agricultural cultivation (CIEL 2006; Hoffmann 2004; Moutari 2008). As the expansion of arable terrain continues, pastoralists are being driven into ever more marginal areas, and cultivators continue to extract the water which feeds pastoral wells.

\section{Implication of the African Union framework policy (PFPA) at national level}

Given the above mentioned scenario, it is a major task to urge Nigeria as one of the member states of the African Union to review policies impacting pastoralism, in accordance with the Policy Framework, to develop a national policy which takes into account the peculiar needs of pastoralism.

The policy framework requires strong buy-in by different stakeholders and should result also in regulatory frameworks that will translate a policy into an enforceable instrument. While development of policy frameworks is a rather simple endeavour, translating policies into legally binding provisions is a rather long and complex exercise, requiring the involvement of a totally different array of experts and institutions.

Design and implementation of sectoral policies need to be based on reliable data. Absence or paucity of good data seriously impairs the development of evidence-based policies and consequently monitoring and assessing their impact. 
It is good at the continental level to have a comprehensive policy aimed at improving the rights and livelihoods of pastoralists, while at the national level we have an action plan for translating the policy dreams into reality. Having a policy at the continental level will support the following:

- A guide to Nigeria actions for securing, protecting and improving the lives, livelihoods and rights of pastoral communities

- A uniform policy on pastoralism across Africa thus promoting regulated movement of pastoralists across international borders

\section{National action plan for implementation of PFPA}

We must be realistic about the existing socio-political set-up which is unfavourable for implementation of the policy framework and plan of action. The country lacks the necessary mechanisms and behaviour for implementation at national and local levels.

It will be wise to consider those negative factors that may obstruct the implementation of the PFPA rather being ambitious and optimistic. For the implementation of the PFPA, there needs to be good governance, good history of policy implementation, strong pastoralist representation, rule of law, ethnic tolerance, etc., but these ideal conditions are not tenable in Nigeria, as in most African states. Therefore, the best option is to be realistic and to come up with a strategy that takes account of institutions, interests and traditions that may hinder the implementation of the PFPA; these include politicisation of public policies; discontinuity and inconsistencies in programme/ project execution; corruption and nepotism, weak application of rules, norms and regulations in the execution of programmes and projects; and misplaced priorities and favouritism.

\section{Differences between a policy and action plan}

Policies and action plans are both important, but serving different purposes. From years of experience as a practitioner and for the purpose of this discourse, the two can be differentiated (see Table 1).

Table 1 Differences between a policy and action plan

\begin{tabular}{ll}
\hline Policy & Action plan \\
\hline $\begin{array}{l}\text { A statement and a guiding principle } \\
\text { for achieving a stated goal; it is more of a theory }\end{array}$ & $\begin{array}{l}\text { A strategy and a guiding principle for achieving } \\
\text { a stated goal in a practical way }\end{array}$ \\
Policies are too ambitious and sometimes utopian & Realistic with the existing circumstances \\
Rigid with little room for review and update & $\begin{array}{l}\text { Flexible; it accommodates monitoring, } \\
\text { evaluation and review }\end{array}$ \\
$\begin{array}{l}\text { It is usually a product of bureaucratic } \\
\text { and political decision-making }\end{array}$ & IA product of research and practice \\
$\begin{array}{l}\text { Optimistic in the achievement of desired } \\
\text { objective without much consideration to factors } \\
\text { that obstruct policy outcome }\end{array}$ & $\begin{array}{l}\text { Consideration to problems and circumstances } \\
\text { in achievement of objectives }\end{array}$ \\
$\begin{array}{l}\text { That the parameters and conditions at the } \\
\text { time of policy making remain static up to the }\end{array}$ & Provision for evaluation and updates \\
time of implementation & \\
\hline
\end{tabular}




\section{Why the need for an action plan}

- Because we have a history of poor policy implementation and faulty pastoral policies

- The need for a paradigm shift from an ambitious but abstract and temporary measure (policy) to a realistic and sustainable solution (action plan) to a problem

- The need for proactive measures in support of a marginalized, vulnerable and voiceless community - the pastoralists.

At this stage, it is difficult to talk of what specific strategies are to be employed; nonetheless, the following may be useful.

\section{Advocacy}

A high level advocacy mechanism is essential to get the support of the government, development partners and civil society. The government has adopted the PFPA. We should capitalize on that to have its commitment for the provision of political support, funds and enabling laws for the National Action Plan (NAP). Such advocacy should also find ways to tailor the economic and technical assistance provided by development partners, and developed nations go to pastoral development. The participation of these organizations in pastoral development will provide a model. Projects in Nigeria by organizations such UNDP, IFAD, World Bank, EEC (now EU), etc. have led to the introduction of community-driven development in rural development.

\section{Baseline information}

A distinguishing factor of an action plan compared to a policy is that it is designed according to existing problems and circumstances. It is necessary to analyse the state of the pastoralists based on past and present interventions. What are their short comings and prospects? A baseline understanding will assist in selecting actions that provide solutions to those short comings and build on the successes. Baseline information should also analyse trends and drivers so that measures can be designed to counter negative trends and fully exploit positive drivers.

\section{Pastoralists' empowerment}

The implementation of the PFPA at national level is expected to be participatory. This calls for a capacity building for the pastoralists. The NAP should find a mechanism to ensure not only that pastoralists are beneficiaries, but also that they actively participate in pastoral development programmes. Any pastoral intervention package that fails to carry along the pastoralists in both planning and implementation is bound to fail, if not suitable to local factors which only the pastoralists could detect and adapt to appropriately.

\section{Conclusions}

The major challenge to Nigeria's policy implementation is simply because we refused to be realistic with our existing predicament, pretending to be what we are not and sweeping problems under the carpet rather than dealing with them. The Nigerian pastoralists 
are lucky to have the Policy Framework for pastoralism in Africa because it is a document designed in accordance with the ideals of pastoralism, based on state-of-the-art thinking on how to enhance livelihoods and the production system. What remains now is for the government to develop and review their pastoral policies and consider how the Framework will be translated into an enforceable instrument through NAP.

Competing interests

The authors declare that they have no competing interests.

Received: 21 May 2012 Accepted: 22 May 2012

Published: 26 July 2012

References

African Union. 2010. Department of Rural Economy and Agriculture Policy framework for pastoralism in Africa: securing, protecting and improving the lives, livelihoods and rights of pastoralist communities. Ethiopia:. http://au.int/en/dp/rea/ content/policy-framework-pastoralism-africa-securing-protecting-and-improving-lives-livelihoods-and-03 july-2012.

Agbese, A., and M. Lalo. 2009. Daily Trust Newspaper. Abuja, Nigeria.

AU. 2010. Executive Council Eighteenth Ordinary Session 24-28 January 2011. Decision on Africa's pastoralism. Addis Ababa Ethiopia: EX.CL/dec/618. Doc. EX.CL/631 (XVIII). http://www.celep.info/?p=263.

CIEL. 2006. CBPR Database - Nigeria, Center for International Environmental Law.. http://www.ciel.org/Publications/ CBPR_Nigeria_9-18-06.pdf.

Ekaete, U. 2001. How we run Nigeria, being the excerpts from the lecture delivered at the Senior Executive Course 23 at the National Institute for Policy and Strategic Studies. Jos: Kuru.

Federal Ministry of Agriculture. 1988. Agricultural Policy for Nigeria. Lagos: Federal Ministry of Agriculture.

Garba, A. 2006. Alleviating poverty in northern Nigeria. Minneapolis, MN, USA: A paper presented at the annual convention of Zumunta Association. July 28-29.

Hesse, C., and O. Odhiambo. 2006. Strengthening pastoralists' voice in shaping policies for sustainable poverty reduction in ASAL regions of East Africa. Nairobi, Kenya: Pastoralists marginalized. Conference on Pastoralism and Poverty Reduction in East Africa: A Policy Research Conference. 27-28 June 2006.

Hoffmann, I. 2004. Access to land and water in the Zamfara Reserve. A case study for the management of common property resources in pastoral areas of West Africa. Human Ecology 32(1): 77-105.

Ibrahim, A. 2006. Mobility management (MOMA)for symbolic relationship between nomadism and the environment: a concept paper for GEF UNDP Project. Katsina State: Department of Town and Country Planning, Ministry of Land Surveys.

Iro, I.S. 1995. From nomadism to sedentarism: an analysis of development constraints and public policy issues in the socioeconomic transformation of the pastoral Fulani of Nigeria. Washington, D. C: University Graduate School in African Studies Department, Howard University.

Moutari, M.S. 2008. Securing pastoralism in East and West Africa: protecting and promoting livestock mobility.. Niger/ Nigeria Desk Review October.

Onibokun, A.G. 1998. Implementation strategies for the National Urban Development Policy for Nigeria. Abuja: Paper presented at the National Workshop on the Modalities of Implementation of the National Urban Policy for Nigeria. June 13-16, 1998.

Oshewolo, S. 2010. Galloping poverty in Nigeria: an appraisal of the government's interventionist policies. Journal of Sustainable Development in Africa 12(6): 271.

VOA. 2009. Voice of America (Hausa Service).Reported on 6-May-2009, 5:00 am local time (Nigeria).

Williams, T.O. 1989. Livestock development in Nigeria: a survey of the policy issues and options. International Livestock Centre for Africa (ILCA): Addis Ababa.

doi:10.1186/2041-7136-2-7

Cite this article as: Ibrahim: Linking vision with reality in the implementation of policy framework for pastoralism in Nigeria. Pastoralism: Research, Policy and Practice 2012 2:7.

\section{Submit your manuscript to a SpringerOpen ${ }^{\circ}$ journal and benefit from:}

- Convenient online submission

- Rigorous peer review

- Immediate publication on acceptance

- Open access: articles freely available online

- High visibility within the field

- Retaining the copyright to your article

Submit your next manuscript at $>$ springeropen.com 